Article

\title{
Dietary Protein Intake Patterns and Inadequate Protein Intake in Older Adults from Four Countries
}

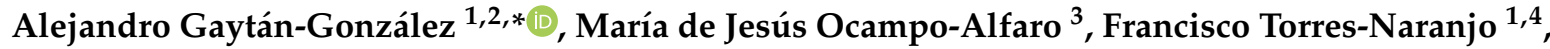 \\ Roberto Gabriel González-Mendoza ${ }^{1} \mathbb{1}$, Martha Gil-Barreiro ${ }^{3}$, Maritza Arroniz-Rivera ${ }^{3}$ \\ and Juan R. López-Taylor ${ }^{1}$ \\ 1 Institute of Applied Sciences for Physical Activity and Sport, Department of Human Movement Sciences, \\ Education, Sport, Recreation, and Dance, University Health Sciences Center, University of Guadalajara, \\ Guadalajara 44430, Mexico; dr.francisco.torres@icloud.com (F.T.-N.); \\ roberto.gonzalez@academicos.udg.mx (R.G.G.-M.); taylor@cucs.udg.mx (J.R.L.-T.) \\ 2 Department of Human Reproduction, Infantile Growth, and Development, University Health Sciences \\ Center, University of Guadalajara, Guadalajara 44280, Mexico \\ 3 Geriatrics Department, Western General Hospital, Zapopan 45170, Mexico; \\ mocampo1@prodigy.net.mx (M.d.J.O.-A.); marthagilbarreiro@yahoo.com.mx (M.G.-B.); \\ marroniz.maritza@gmail.com (M.A.-R.) \\ 4 Center of Body Composition and Bone Research, Guadalajara 44600, Mexico \\ * Correspondence: alejandro.gaytan@cucs.udg.mx; Tel.: +52-1-333-619-9708
}

Received: 20 August 2020; Accepted: 9 October 2020; Published: 16 October 2020

\begin{abstract}
Recent interest in protein intake per meal is observed in studies that have reported the protein intake patterns in different countries; however, comparisons of these data are lacking. We aimed to compare protein intake patterns and the percentage of inadequate protein intake (IPI) per day and meal in older adults from different countries. We acquired data of protein intake in older adults from four countries (Mexico, United States of America, Germany, and United Kingdom). We compared protein intake (per day and meal), IPI per day and meal, and the number of meals with an adequate protein content among countries. The IPI per day significantly differed among countries for $<0.8$ and $<1.0$ (both $p<0.001$ ), but not for $<1.2 \mathrm{~g} / \mathrm{kg} / \mathrm{d}(p=0.135)$. IPI per meal $(<30 \mathrm{~g} / \mathrm{meal}$ ) did not differ among countries at breakfast $(p=0.287)$ and lunch $(p=0.076)$ but did differ at dinner $(p<0.001)$. Conversely, IPI per meal $(<0.4 \mathrm{~g} / \mathrm{kg} / \mathrm{meal})$ significantly differed among countries at breakfast, lunch, and dinner (all $p<0.001$ ). The percentage of participants that ate $\geq 30 \mathrm{~g} / \mathrm{meal}$ or $\geq 0.4 \mathrm{~g} / \mathrm{kg} / \mathrm{meal}$ at zero, one, and two or three meals per day significantly differed among countries (all $p<0.05$ ). IPI at breakfast and lunch $(<30 \mathrm{~g} /$ meal) was a common trait in the analyzed samples and might represent an opportunity for nutritional interventions in older adults in different countries.
\end{abstract}

Keywords: breakfast; meals; older adults; protein intake

\section{Introduction}

The ageing process in humans encompasses many changes that ultimately lead to undesirable clinical conditions like a higher fat deposition, osteoporosis, sarcopenia, frailty, and physical disability $[1,2]$. Current research on ageing focuses on decreasing the risk of developing the previously mentioned conditions and designing effective interventions to improve the patient's health [3-5].

Regarding sarcopenia, frailty, and physical disability, protein intake is one of the several factors linked to these clinical conditions [6]. A growing body of evidence suggests that daily protein intake above the recommended dietary allowance (R.D.A.) of $0.8 \mathrm{~g} / \mathrm{kg} / \mathrm{d}$ is associated with better physical performance, maintenance or even an increase in muscle mass, and decreased risk of physical 
disability. Therefore, it has been suggested to set the protein recommendation to a higher dose of $1.0-1.2 \mathrm{~g} / \mathrm{kg} / \mathrm{d}[7-10]$.

Additionally, it seems that other traits, like protein intake per meal and protein distribution, should be considered along with daily protein intake [11,12]. Nonetheless, the evidence is equivocal; other studies suggest that the protein intake pattern might not be an important variable to consider in terms of skeletal muscle-related outcomes (e.g., strength and functionality) [12-14]. The studies supporting the importance of protein distribution in older adults suggest that the consumption of $30 \mathrm{~g}$ of protein per meal or $0.4 \mathrm{~g} / \mathrm{kg}$ per meal are associated with a higher skeletal muscle mass and strength and maximally stimulates muscle protein synthesis, respectively $[15,16]$. In this regard, some studies suggested that inadequate protein intake $(<30 \mathrm{~g} / \mathrm{meal}$ or $<0.4 \mathrm{~g} / \mathrm{kg} / \mathrm{meal})$ at specific meals might be a risk factor to consider as it is associated to a lower skeletal muscle mass, muscle strength, and functionality [17-19]. On the other hand, the number of meals that reach a protein content $\geq 30 \mathrm{~g} / \mathrm{meal}$ or $\geq 0.4 \mathrm{~g} / \mathrm{kg} / \mathrm{meal}$ appears to be a protective factor as they are associated with a higher skeletal muscle mass, muscle strength, and lower physical disability $[15,20,21]$. Therefore, determining the percentage of older adults for both indicators might help visualize the magnitude of these two possible risk and protective factors.

Several studies have focused their attention on analyzing dietary protein intake patterns in older adults in different countries [14,19-27]. Nonetheless, to the best of our knowledge, direct comparisons of protein intake patterns among countries are lacking [28]. Similarly, the comparison of the percentage of older adults that did not eat enough protein per day (i.e., $0.8,1.0$, and $1.2 \mathrm{~g} / \mathrm{kg} / \mathrm{d}$ ) or per meal $(30 \mathrm{~g} / \mathrm{meal} ; 0.4 \mathrm{~g} / \mathrm{kg} / \mathrm{meal})$ among countries is missing. These comparisons among countries might serve as a starting point to understand the magnitude of this situation, because comparisons would help us to determine if these different samples share common issues, allowing us to identify protein-eating patterns to be improved.

Therefore, this exploratory study aimed to (1) compare dietary protein intake patterns among older adults from four countries, (2) report and compare data of inadequate protein intake per day and per meal among older adults from four countries, and (3) analyze if these comparisons would yield similar results when the analysis was separated by sex. We hypothesized that dietary protein intake patterns would be different, but inadequate protein intake would be similar among countries. Likewise, we hypothesized that the comparisons among countries separated by sex would yield different patterns (e.g., if protein at breakfast differs among countries in women but not in men) and that the whole sample pattern would be the same in women but not in men.

\section{Materials and Methods}

\subsection{Study Design and Data Acquisition}

This is an exploratory analysis carried out with data from previously published articles where authors reported protein intake per day and meal in adults aged $\geq 60$ years. Corresponding authors were contacted to gather demographic and protein intake data. We acquired data from two studies of two countries (Germany [14] and the United Kingdom [U.K.] [24]), from the National Health and Nutrition Examination Survey (NHANES) 2015-2016 publicly available database representing the United States of America (U.S.A.) [29], and data from our previous work in Mexico [18,20], all with cross-sectional designs. 
To analyze the NHANES sample, we included data from participants with the following characteristics: (1) aged $\geq 60$ year; (2) they were born in the U.S.A.; (3) reported an energy intake $\geq 600$ and $\leq 4000 \mathrm{kcal} /$ day; and (4) had complete data for age, height, and body mass. From these records ( $n=1039,50 \%$ women), we randomly selected 200 subjects (100 per sex to keep the sex proportion) to decrease the differences in sample size among groups. There were no significant differences between included and nonincluded subjects $(n=839)$ for age $(p=0.81)$, body mass $(p=0.55)$, height $(p=0.38)$, BMI $(p=0.98)$, nor total protein intake per day $(p=0.15)$. This sample was not weighted according to the NHANES complex study design as the other studies did not follow the same sampling design.

All studies independently coded the three main meals (i.e., breakfast, lunch, and dinner), and reported that they obtained participants' written informed consent and ethical approval from their local institution before any assessment. Table 1 shows an overview of the included samples.

\subsection{Protein Intake Variables}

When studies reported two or more days of dietary assessment, we averaged the protein intake per day and per meal, and we used these averages for further analysis. We calculated relative protein intake per day (g/kg body mass/d) and per meal (g/kg body mass/meal), meal contribution to total daily protein $(\%)$, and protein distribution coefficient of variation in addition to the absolute protein intake per day $(\mathrm{g} / \mathrm{d})$ and per meal $(\mathrm{g} / \mathrm{meal})$.

Meal contribution to total protein was calculated as:

$$
\text { Meal contributrion }=P M / T P \times 100,
$$

where $P M$ is the protein reported for any given meal $(\mathrm{g})$ and $T P$ is the total daily protein intake $(\mathrm{g})$.

The protein distribution coefficient of variation $(P D C V)$ was calculated as:

$$
P D C V=S D P / M P
$$

where $S D P$ is the standard deviation of the three main meals and $M P$ is the mean protein intake for the three main meals.

\subsection{Inadequate Protein Intake}

Inadequate protein intake (IPI) was considered as any protein consumption $<0.8$ (IPID-0.8), $<1.0$ (IPID-1.0), and $<1.2$ (IPID-1.2) g/kg/d [7,8] or $<30 \mathrm{~g} / \mathrm{meal}$ (IPIM-30) and $<0.4 \mathrm{~g} / \mathrm{kg} / \mathrm{meal}$ (IPIM-0.4) [15,16]. We reported IPIM-30 and IPIM-0.4 for each main meal. We also counted the number of meals per day (coded as zero $[0 \mathrm{M}]$, one $[1 \mathrm{M}]$, and two or three meals $[+2 \mathrm{M}]$ ) with $\geq 30 \mathrm{~g}$ protein and $\geq 0.4$ g protein $/ \mathrm{kg}$ each. 
Table 1. Description of studies' main characteristics.

\begin{tabular}{|c|c|c|c|c|c|c|c|}
\hline Author (Year) & City and Country & $\begin{array}{c}\text { Year of } \\
\text { Recruitment }\end{array}$ & $\begin{array}{c}\text { Sample Size } \\
\text { (W/M) }\end{array}$ & Representativity & Setting & Recruitment & Food Assessment Tool \\
\hline Gaytán-González (2020) [20] & Zapopan, Mexico & 2017 & $\begin{array}{c}187 \\
(140 / 47)\end{array}$ & Local & Community-dwelling & $\begin{array}{l}\text { Users of a tertiary } \\
\text { care hospital }\end{array}$ & One 24-h dietary recall \\
\hline NHANES, 2015-2016 [29] & United States of America & 2015-2016 & $\begin{array}{c}200 \\
(100 / 100)\end{array}$ & National $\ddagger$ & Community-dwelling & $\begin{array}{l}\text { Random selection from } \\
\text { the national census }\end{array}$ & $\begin{array}{c}\text { Two nonconsecutive 24-h } \\
\text { dietary recall }\end{array}$ \\
\hline Gingrich (2017) [14] & Nürnberg, Germany & 2016-2017 & $\begin{array}{c}97 \\
(48 / 49)\end{array}$ & Local & Community-dwelling & Citizen registry & 7-day food record \\
\hline Cardon-Thomas (2018) [24] & Birmingham, United Kingdom & 2014 & $\begin{array}{c}38 \\
(26 / 12)\end{array}$ & Local & Community-dwelling & Volunteer databases & 3-day food diary \\
\hline
\end{tabular}

NHANES: National Health and Nutrition Examination Survey; W/M: number of women and men. ‡ The complex sampling design of NHANES leads to nationally representative data; however, this is not the case for this study as the data were not weighted according to its sampling design and were composed of a smaller sample size (200 vs. 1039). 


\subsection{Statistics}

Continuous data were expressed in mean \pm standard deviation, while categorical and ordinal data in frequencies, percentages, and $95 \%$ confidence intervals. To compare the continuous variables among countries, we performed one-way ANOVAs with Scheffe test as post hoc when Levene's test suggested homogeneity of variances $(p>0.05)$. Otherwise, one-way ANOVAs with Welch's correction and Dunnett T3 test as post hoc were performed (Microsoft ${ }^{\circledR}$ Excel ${ }^{\circledR}$ 2013, Microsoft Corporation, Redmond, WA, USA). To compare the categorical and ordinal variables among countries, we used the $\chi^{2}$ test of independence (GraphPad Prism 7.05, GraphPad Software Inc., La Jolla, CA, USA) and multiple $t$-tests for proportions with Bonferroni correction as post hoc (Statistics calculator v4.0, StatPac, Northfield, MN, USA). All comparisons were deemed significant at a $p$-value $\leq 0.05$. Effect sizes were calculated for ANOVAs (omega squared, $\omega^{2}$ ) and $\chi^{2}$ tests of independence (phi statistic, $\varphi$ ). Both effect size statistics are dimensionless and range between 0 and 1 . An effect size was considered small, medium, or large if $\omega^{2}$ reached $0.01,0.06$, or 0.14 , respectively; the respective values for $\varphi$ were $0.1,0.3$, 0.5 [30,31]. Effect sizes below the "small" cut point were considered trivial [32]. The difference between the highest mean and the lowest mean was reported along with the effect size. The comparisons among countries were carried out for the whole sample and separated by sex.

\section{Results}

\subsection{Demographic Data}

There were significant differences among countries for all demographic data. Mexico showed the highest women proportion while Germany the lowest ( $25 \%$ difference, small effect). Age, body mass, and height comparisons showed a large effect. The oldest participants came from Mexico, Germany, and U.K. in contrast to those in U.S.A. (8-year difference). The heaviest participants belonged to U.S.A. (20 kg difference vs. Mexico), and U.S.A. and Germany showed the tallest participants $(13 \mathrm{~cm}$ difference vs. Mexico). The B.M.I. comparison showed a medium effect with U.S.A. having the heaviest participants (3.3 units difference vs. Germany) (Table 2). A similar pattern was observed in women (Table S1) and men (Table S2).

\subsection{Protein Intake}

For absolute protein intake (g), U.K., U.S.A., and Germany showed the highest protein consumption per day (19 g difference vs. Mexico, medium effect). Mexico, U.S.A., and Germany showed the highest intake at breakfast ( $3 \mathrm{~g}$ difference vs. U.K., trivial effect). In comparison, U.K. and U.S.A. showed the highest intake at dinner ( $20 \mathrm{~g}$ difference vs. Mexico, large effect). There were no significant differences among countries for protein intake at lunch (Table 2).

For relative protein intake $(\mathrm{g} / \mathrm{kg})$, U.K. showed the highest intake per day $(0.22 \mathrm{~g} / \mathrm{kg}$ difference vs. U.S.A., small effect). Mexico showed the highest intake at breakfast $(0.09 \mathrm{~g} / \mathrm{kg}$ difference vs. U.S.A., medium effect). U.K. and Mexico showed the highest intake at lunch $(0.15 \mathrm{~g} / \mathrm{kg}$ difference vs. U.S.A., medium effect). U.K. showed the highest intake at dinner $(0.29 \mathrm{~g} / \mathrm{kg}$ difference vs. Mexico, large effect) (Table 2).

Analyzing the percentage of meal contribution to total protein intake, Germany, and Mexico ate most of their daily protein at lunch, whereas U.S.A. and U.K. did it at dinner. Mexico showed the highest breakfast (13\% difference vs. U.K., medium effect) and lunch contribution ( $12 \%$ difference vs. U.S.A., medium effect), whereas U.S.A. and U.K. showed the highest dinner contribution (19\% difference vs. Mexico, large effect). In terms of the PDCV, Germany showed the evenest protein distribution ( -0.17 units difference vs. U.K., small effect) (Table 2). The comparisons divided by sex showed a very similar pattern to that observed of the whole sample, with slight differences in which countries differ from one another (Tables S1 and S2). However, it is remarkable that there were no significant differences among countries at breakfast and lunch $(\mathrm{g})$ nor per day and breakfast $(\mathrm{g} / \mathrm{kg})$ in men (Table S2). 
Table 2. Participants' main characteristics and protein intake variables by country.

\begin{tabular}{|c|c|c|c|c|c|c|c|}
\hline & Mexico & U.S.A. & Germany & United Kingdom & $p$-Value & \multicolumn{2}{|c|}{ Effect Size } \\
\hline$n$ & 187 & 200 & 97 & 38 & & & \\
\hline Women (\%) & $74.9 \mathrm{a}$ & $50.0 \mathrm{~b}$ & $49.5 \mathrm{~b}$ & $68.4 \mathrm{a}, \mathrm{b}$ & $<0.001$ & 0.244 & $S$ \\
\hline Age (year) & $79 \pm 8 a$ & $71 \pm 7 \mathrm{~b}$ & $78 \pm 3 a$ & $78 \pm 5 a$ & $<0.001$ & 0.226 & $\mathrm{~L}$ \\
\hline Body mass $(\mathrm{kg})$ & $63.2 \pm 13.1 \mathrm{a}$ & $83.8 \pm 19.6 \mathrm{~b}$ & $74.1 \pm 14.0 \mathrm{c}$ & $68.0 \pm 12.0 \mathrm{a}, \mathrm{c}$ & $<0.001$ & 0.238 & $\mathrm{~L}$ \\
\hline Height $(\mathrm{cm})$ & $153.6 \pm 9.1 \mathrm{a}$ & $166.6 \pm 10.3 \mathrm{~b}$ & $166.1 \pm 9.2 \mathrm{~b}$ & -+ & $<0.001$ & 0.297 & $\mathrm{~L}$ \\
\hline $\mathrm{BMI}\left(\mathrm{kg} / \mathrm{m}^{2}\right)$ & $26.9 \pm 5.7 \mathrm{a}$ & $30.1 \pm 6.0 \mathrm{~b}$ & $26.8 \pm 4.0 \mathrm{a}$ & -+ & $<0.001$ & 0.074 & $\mathrm{M}$ \\
\hline \multicolumn{8}{|c|}{ Absolute protein intake $(\mathrm{g})$} \\
\hline Day & $57 \pm 20 a$ & $74 \pm 28 b$ & $70 \pm 19 b$ & $76 \pm 12 b$ & $<0.001$ & 0.111 & M \\
\hline Breakfast & $17 \pm 8 \mathrm{a}$ & $16 \pm 10 \mathrm{a}, \mathrm{b}$ & $16 \pm 9 a, b$ & $14 \pm 6 \mathrm{~b}$ & 0.023 & 0.006 & $\mathrm{~T}$ \\
\hline Lunch & $25 \pm 12$ & $23 \pm 14$ & $24 \pm 10$ & $29 \pm 14$ & 0.098 & 0.009 & $\mathrm{~T}$ \\
\hline Dinner & $13 \pm 8 a$ & $30 \pm 17 b$ & $22 \pm 11 c$ & $33 \pm 12 b$ & $<0.001$ & 0.275 & $\mathrm{~L}$ \\
\hline \multicolumn{8}{|c|}{ Relative protein intake $(\mathrm{g} / \mathrm{kg})$} \\
\hline Day & $0.93 \pm 0.37 \mathrm{a}$ & $0.92 \pm 0.38 \mathrm{a}$ & $0.97 \pm 0.28 \mathrm{a}$ & $1.14 \pm 0.25 b$ & $<0.001$ & 0.019 & $\mathrm{~S}$ \\
\hline Breakfast & $0.29 \pm 0.16 \mathrm{a}$ & $0.20 \pm 0.13 b$ & $0.23 \pm 0.12 b$ & $0.21 \pm 0.10 \mathrm{~b}$ & $<0.001$ & 0.077 & $\mathrm{M}$ \\
\hline Lunch & $0.41 \pm 0.22 \mathrm{a}$ & $0.28 \pm 0.19 b$ & $0.33 \pm 0.14 c$ & $0.43 \pm 0.23 a, c$ & $<0.001$ & 0.082 & M \\
\hline Dinner & $0.21 \pm 0.14 \mathrm{a}$ & $0.37 \pm 0.22 b$ & $0.30 \pm 0.14 c$ & $0.50 \pm 0.19 \mathrm{~d}$ & $<0.001$ & 0.196 & $\mathrm{~L}$ \\
\hline \multicolumn{8}{|c|}{ Daily contribution (\%) } \\
\hline Breakfast & $32 \pm 14 \mathrm{a}$ & $22 \pm 13 b, c$ & $23 \pm 10 b$ & $19 \pm 8 c$ & $<0.001$ & 0.126 & $\mathrm{M}$ \\
\hline Lunch & $43 \pm 15 a$ & $31 \pm 16 \mathrm{~b}$ & $35 \pm 12 b$ & $38 \pm 16 a, b$ & $<0.001$ & 0.114 & $\mathrm{M}$ \\
\hline Dinner & $23 \pm 12 a$ & $40 \pm 16 b$ & $31 \pm 11 c$ & $44 \pm 15 b$ & $<0.001$ & 0.268 & $\mathrm{~L}$ \\
\hline PDCV & $0.55 \pm 0.26 \mathrm{a}$ & $0.59 \pm 0.28 a$ & $0.43 \pm 0.24 b$ & $0.60 \pm 0.18 a$ & $<0.001$ & 0.044 & $\mathrm{~S}$ \\
\hline
\end{tabular}

† Data not obtained. BMI: Body Mass Index; $\mathrm{g} / \mathrm{kg}$ : grams of protein per kilogram of body mass; L: large effect size; M: medium effect size; PDCV: protein distribution coefficient of variation (dimensionless); S: small effect size; T: trivial effect size; U.S.A.: United States of America. Countries not sharing a similar letter denote significant differences among them ( $p \leq 0.05)$ within each variable. 


\subsection{Inadequate Protein Intake per Day}

There were significant differences among countries for IPID-0.8, IPID-1.0, but not IPID-1.2. For IPID-0.8, the highest percentage was observed in U.S.A. (43.0\%) and Mexico (42.2\%) (35\% difference vs. U.K., small effect). For IPID-1.0, U.S.A. (61.5\%), Mexico (61.5\%), and Germany (60.8\%) showed the highest percentages (35\% difference vs. U.K., small effect). For IPID-1.2, percentages ranged from $65.8 \%$ in U.K. to $83.5 \%$ in Germany (Figure 1). A similar pattern was observed in women. However, in men, there were no significant differences among countries for any cut point (Figure S1).

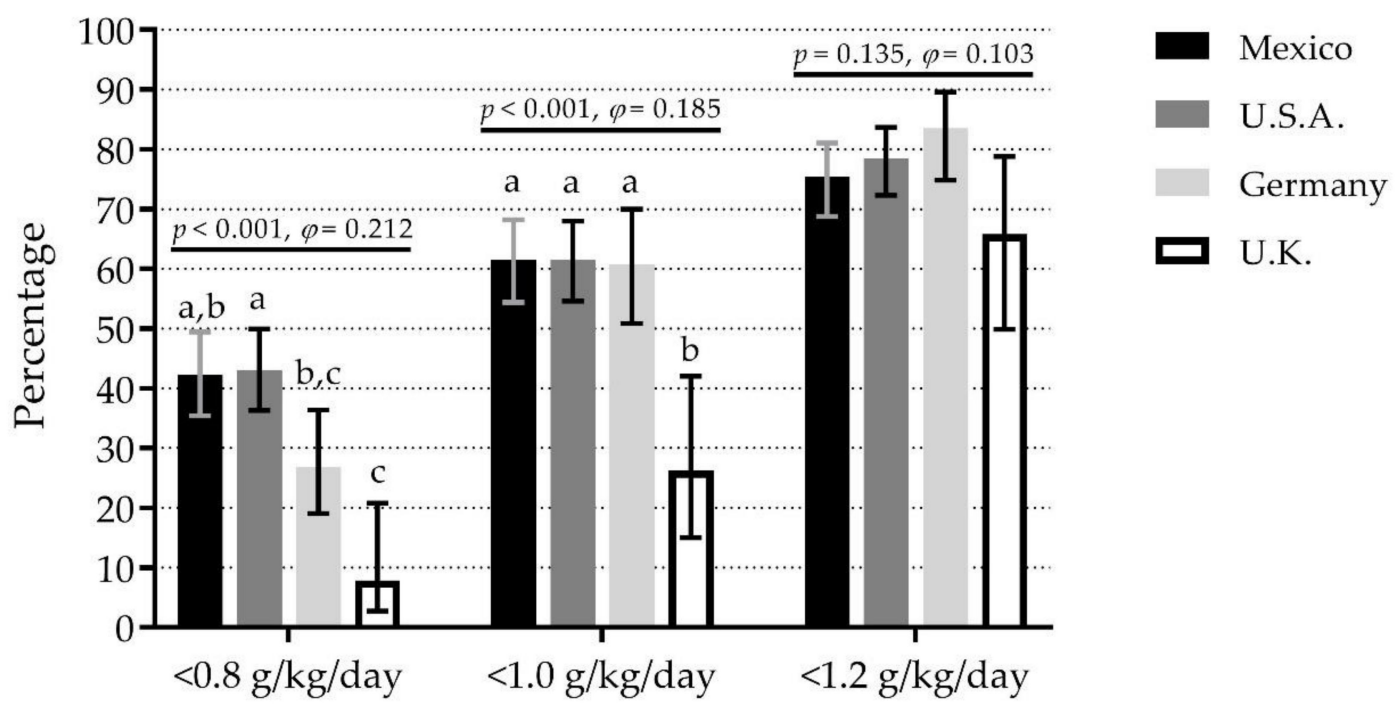

Figure 1. Comparison of inadequate protein intake per day with different cut points among four countries. Bars represent the percentage of inadequate protein intake per day; whiskers represent $95 \%$ confidence intervals. $p$-values and $\varphi$ statistic are for comparisons among countries within cut points ( $\chi^{2}$ test of independence). Bars not sharing a similar letter $(a, b, c)$ denote significant differences $(p \leq 0.05)$ among countries within cut points ( $t$-test for proportions with Bonferroni correction). $\mathrm{g} / \mathrm{kg} / \mathrm{day}$ : grams of protein per kilogram of body mass per day; U.K.: United Kingdom; U.S.A.: United States of America. Detailed data can be found in Table S3.

\subsection{Inadequate Protein Intake per Meal}

For IPIM-30, there were no significant differences among countries at breakfast (range $91.5 \%$ in U.S.A. to $97.4 \%$ in U.K.) and lunch (range $63.2 \%$ in U.K. to $77.0 \%$ in U.S.A.). However, there were significant differences at dinner, where Mexico (96.8\%) showed the highest percentage (60\% difference vs. U.K., medium effect) (Figure 2a). The pattern was very similar when comparisons were separated by sex (Figure S2a,b).

For IPIM-0.4, there were significant differences among countries for the three meals. At breakfast, U.K. $(97.4 \%)$, U.S.A. (94.0\%), and Germany $(90.7 \%)$ showed the highest percentages ( $20 \%$ difference vs. Mexico, small effect). At lunch, U.S.A. (80.5\%) and Germany (72.2\%) showed the highest percentages (31\% difference vs. Mexico, small effect). At dinner, Mexico (92.0\%) showed the highest percentage (61\% difference vs. U.K., medium effect) (Figure $2 b$ ). The pattern was very similar when comparisons were separated by sex (Figure S2c,d). 


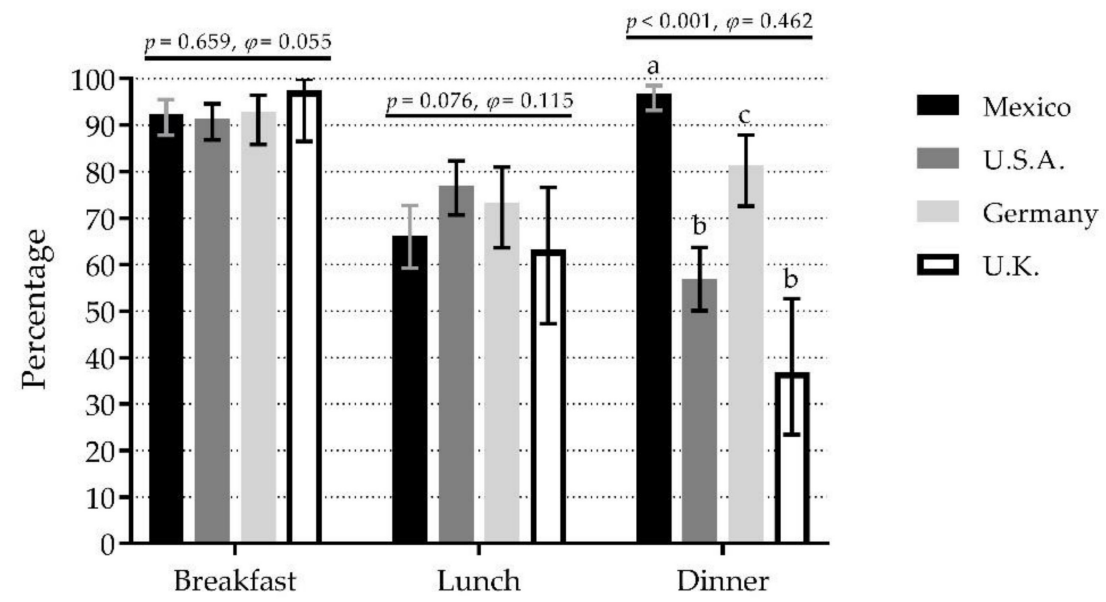

(a)

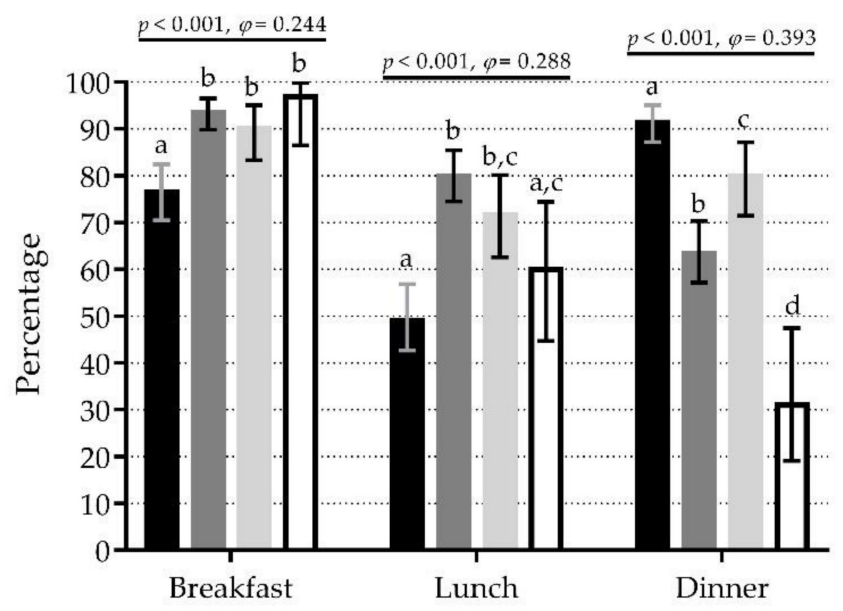

(b)

Figure 2. Comparison of inadequate protein intake per meal (breakfast, lunch, and dinner) among four countries depending on the protein content at each meal as $<30 \mathrm{~g} /$ meal (a) or $<0.4 \mathrm{~g} / \mathrm{kg}$ body mass/meal (b). Bars represent the percentage of inadequate protein intake per meal; whiskers represent $95 \%$ confidence intervals. $p$-values and $\varphi$ statistic are for comparisons among countries within meals ( $\chi^{2}$ test of independence). Bars not sharing a similar letter ( $\left.a, b, c, d\right)$ denote significant differences $(p \leq 0.05)$ among countries within meals ( $t$-test for proportions with Bonferroni correction). U.K.: United Kingdom; U.S.A.: United States of America. Detailed data can be found in Table S3.

\subsection{Number of Meals per Day with Adequate Protein Content}

When the $\geq 30 \mathrm{~g}$ protein/meal criterion was used, Mexico $(61.0 \%)$ and Germany $(60.8 \%)$ showed the highest percentages of $0 \mathrm{M}$ ( $50 \%$ difference vs. U.K., small effect), U.K. (76.3\%) showed the highest percentage of $1 \mathrm{M}$ ( $48 \%$ difference vs. Germany, small effect), whereas U.S.A. (14.5\%) showed the highest percentage of $+2 \mathrm{M}(10 \%$ difference vs. Mexico, small effect) (Figure 3a). The pattern was similar when comparisons were separated by sex, except there were no significant differences among countries for $+2 \mathrm{M}$ for either sex (Figure S3a,b). 

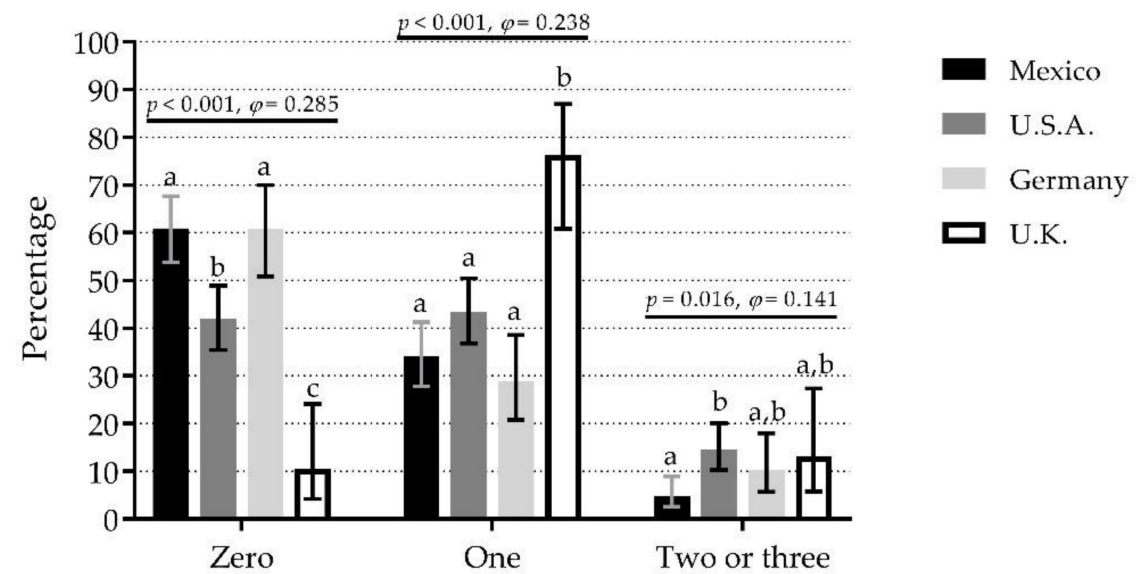

(a)

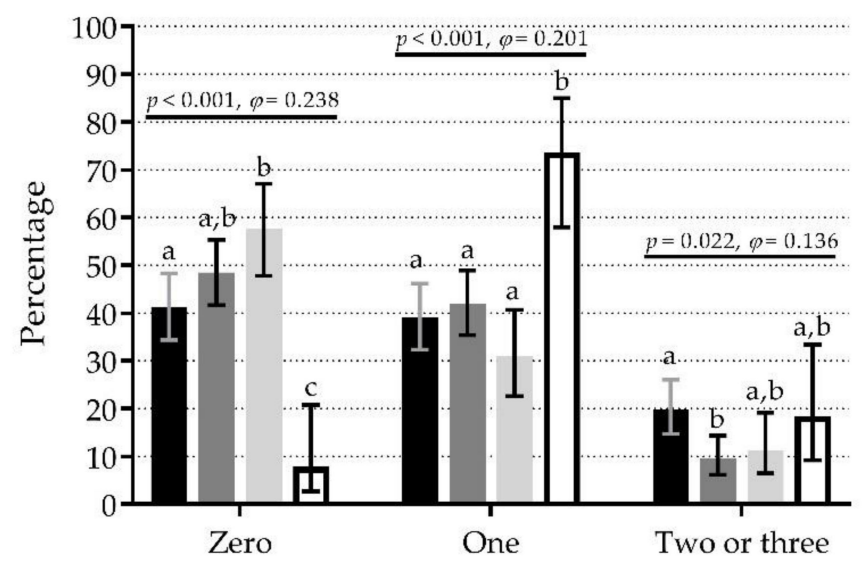

(b)

\section{Number of meals per day}

Figure 3. The number of meals per day containing $\geq 30 \mathrm{~g}$ protein (a) or $\geq 0.4 \mathrm{~g}$ protein $/ \mathrm{kg}$ body mass (b) compared among countries. Bars represent the percentage of participants that reported the number of meals per day (zero, one, and two or three) with the mentioned protein content; whiskers represent $95 \%$ confidence intervals. $p$-values and $\varphi$ statistic are for comparisons among countries within the number of meals ( $\chi^{2}$ test of independence). Bars not sharing a similar letter $(a, b, c)$ denote significant differences $(p \leq 0.05)$ among countries within the number of meals ( $t$-test for proportions with Bonferroni correction). U.K.: United Kingdom; U.S.A.: United States of America. Detailed data can be found in Table S3.

When the $\geq 0.4 \mathrm{~g}$ protein $/ \mathrm{kg} / \mathrm{meal}$ criterion was used, Germany $(57.7 \%)$ and U.S.A. (48.5\%) showed the highest percentages of 0M (50\% difference vs. U.K., small effect), whereas U.K. (73.7\%) showed the highest percentage of $1 \mathrm{M}(42 \%$ difference vs. Germany, small effect). In contrast, Mexico (19.8\%) showed the highest percentage of $+2 \mathrm{M}(10 \%$ difference vs. U.S.A., small effect) (Figure $3 \mathrm{~b})$. The comparisons separated by sex showed a different pattern to that observed in the whole sample. In women, there were significant differences among countries for $0 \mathrm{M}$ and $1 \mathrm{M}$, but not for $+2 \mathrm{M}$ groups (Figure $\mathrm{S} 3 \mathrm{c}$ ). In men, there were significant differences among countries for $0 \mathrm{M}$, but not for $1 \mathrm{M}$ and $+2 \mathrm{M}$ groups (Figure $\mathrm{S} 3 \mathrm{~d}$ ). 


\subsection{IPI Combined Results}

When data from the four samples were combined $(n=522)$, we calculated the percentage of IPID-0.8, IPID-1.0, IPID-1.2, IPIM-30, IPIM-0.4, and the number of meals with an adequate protein content (Table 3). Briefly, we observed that there was about a $20 \%$ increase in the percentage of IPI per day every time when the cut point was increased. For both IPIM-30 and IPIM-0.4, breakfast was the meal with the highest percentage, followed by dinner and lunch. For both $\geq 30 \mathrm{~g} / \mathrm{meal}$ and $\geq 0.4 \mathrm{~g} / \mathrm{kg} / \mathrm{meal}$ criteria, eating $0 \mathrm{M}$ was the most condition, followed by $1 \mathrm{M}$ and $+2 \mathrm{M}$.

Table 3. Combined data $(n=522)$ from the four samples analyzed.

\begin{tabular}{|c|c|c|c|}
\hline & $n$ & $(\%)$ & $(95 \% \mathrm{CI})$ \\
\hline IPID-0.8 & 194 & (37.2) & $(33.1-41.4)$ \\
\hline IPID-1.0 & 307 & $(58.8)$ & $(54.5-63.0)$ \\
\hline IPID-1.2 & 404 & $(77.4)$ & $(73.6-80.8)$ \\
\hline \multicolumn{4}{|c|}{ IPIM-30 } \\
\hline Breakfast & 483 & $(92.5)$ & (89.9-94.5) \\
\hline Lunch & 373 & $(71.5)$ & $(67.4-75.2)$ \\
\hline Dinner & 388 & $(74.3)$ & $(70.4-77.9)$ \\
\hline \multicolumn{4}{|c|}{ IPIM-0.4 } \\
\hline Breakfast & 457 & (87.5) & $(84.4-90.1)$ \\
\hline Lunch & 347 & $(66.5)$ & $(62.3-70.4)$ \\
\hline Dinner & 390 & $(74.7)$ & $(70.8-78.3)$ \\
\hline \multicolumn{4}{|c|}{ Number of meals with $\geq 30 \mathrm{~g} / \mathrm{meal}$} \\
\hline Zero & 261 & (50.0) & $(45.7-54.3)$ \\
\hline One & 208 & $(39.8)$ & $(35.7-44.1)$ \\
\hline Two or three & 53 & $(10.2)$ & $(7.8-13.0)$ \\
\hline \multicolumn{4}{|c|}{ Number of meals with $\geq 0.4 \mathrm{~g} / \mathrm{kg} / \mathrm{meal}$} \\
\hline Zero & 233 & (44.6) & $(40.4-48.9)$ \\
\hline One & 215 & $(41.2)$ & $(37.0-45.5)$ \\
\hline Two or three & 74 & (14.2) & (11.4-17.4) \\
\hline
\end{tabular}

95\% CI: 95\% confidence intervals; IPID-0.8: inadequate protein intake per day $(<0.8 \mathrm{~g} / \mathrm{kg} / \mathrm{d}) ;$ IPID-1.0: inadequate protein intake per day $(<1.0 \mathrm{~g} / \mathrm{kg} / \mathrm{d})$; IPID-1.2: inadequate protein intake per day $(<1.2 \mathrm{~g} / \mathrm{kg} / \mathrm{d})$; IPIM-30: inadequate protein intake per meal ( $<30 \mathrm{~g} / \mathrm{meal})$; IPIM-0.4: inadequate protein intake per meal $(<0.4 \mathrm{~g} / \mathrm{kg} / \mathrm{meal})$.

\section{Discussion}

To the best of our knowledge, this is the first study that compares dietary protein intake patterns and the percentage of IPI per day and per meal among countries. While there are studies where dietary protein intake patterns were reported, direct evidence about their differences was lacking. This study demonstrates that some dietary protein intake patterns in older adults significantly differed among countries, but they shared traits in IPI. For instance, three countries showed a similar percentage of IPID-1.0 (>60\%) and IPID-1.2 (>75\%) (Figure 1). These high percentages of IPI per day might represent a higher risk of lower physical functioning $[9,10,33]$ and developing frailty $[34,35]$.

Furthermore, the main finding of this study was that participants from all the analyzed samples reported a high percentage of IPIM-30 at breakfast $(>90 \%)$ and lunch $(>60 \%)$ (Figure $2 a)$. This is relevant due to IPI at breakfast might also be attributable to breakfast skipping [36]. Although breakfast skipping is less studied in older adults, evidence in their younger counterparts offers insight about what to expect. For example, breakfast skipping was associated with lower skeletal muscle mass in young adults [37], which seems feasible in older adults because meal skipping might lead to malnutrition [38] and skeletal muscle loss [39]. Additionally, breakfast skipping is associated with a higher risk of developing type 2 diabetes in adults of different ages (18-83 year) [40]. Moreover, breakfast has been previously reported as a low-energy containing meal [36]. For instance, Huseinovic et al. [28] reported 
that breakfast composed the lowest contribution to the daily energy intake in different European countries, which we speculate might include IPIM-30. On the other hand, insufficient protein intake at lunch is also associated with lower functionality and muscle mass decline [18,19]. Both eating occasions might represent an opportunity for nutritional interventions in older adults in many countries; however, breakfast appears to be a priority due to its larger percentage of inadequate protein intake.

We observed that most differences among countries could be attributable to women because the pattern was very similar to that observed in the whole sample. However, while it appears to be a sex-derived pattern in some variables (e.g., protein at breakfast and lunch), it is important to highlight that there were more women than men in this analysis. Therefore, men could be underrepresented and different patterns attributable to different sample sizes. Further research among countries with larger men samples is recommended.

As previously mentioned, the evidence comparing eating patterns among countries is scarce, and the available studies are focused on eating occasions, meal frequency, and meal energy content, rather than protein intake per meal $[28,36,41]$. Therefore, it is difficult to draw comparisons with the previous evidence. However, we can see that our results are supported by drawing inferences from other studies; i.e., IPI per day may differ among countries [42,43], but IPI at breakfast appears to be high $[43,44]$. Although an "all countries" comparison might not be reliable, we believe it would be of interest to compare countries sharing a geographical area (e.g., North America, South America, and Western Europe) and among states/provinces within countries. It would lead to data about the magnitude of the problem in specific regions to design concrete strategies to overcome this problem.

Another important finding is that about $90 \%, 70 \%$, and $74 \%$ of the participants did not eat enough protein at breakfast, lunch, and dinner, respectively (Table 3). Therefore, there is interest in strategies to increase total dietary protein intake $[4,5,45]$. We [20] and others $[15,21,46]$ have previously reported that reaching an adequate protein content per meal (i.e., $\geq 30 \mathrm{~g}$ ) is significantly associated with higher daily protein intake and lower proportion of IPI per day $(<1.2 \mathrm{~g} / \mathrm{kg} / \mathrm{d})$. However, this practice is not usual. We reported here that only about $15 \%$ of participants ate two or three meals with adequate protein content (Table 3). This low proportion of compliance might be attributable to the lack of appetite and some chewing difficulties commonly observed in older adults $[5,6,47]$, thus making it challenging to reach this protein amount with simple foods [47]. Some strategies, like mincing meat [48] and food enrichment with protein [46], may help overcome the difficulties mentioned earlier. On the other hand, about $45 \%$ of the participants did not eat enough protein at any meal (Table 3 ), which may be a concern because their muscle protein synthesis might not be stimulated to its maximum level at any meal [11]. This low protein intake might lead to a negative protein balance, muscle loss, and possibly accelerating the functional decline in the elderly [49,50].

In this study, the combined data suggested that about $40 \%, 60 \%$, and $80 \%$ of the participants showed IPI per day for the $<0.8,<1.0$, and $<1.2 \mathrm{~g} / \mathrm{kg}$ criteria (Table 3 ). These results are similar to those recently reported by Hengeveld et al. [51]. In their meta-analysis, they found that when protein intake was divided by the actual body weight ( $\mathrm{g} / \mathrm{kg}$ of actual body weight/day), the IPI was 29.1, 54.3 , and $75.7 \%$, respectively. Nevertheless, when they used the adjusted body weight (g/kg adjusted body weight/day), the percentages of IPI were lower, $21.5 \%, 46.7 \%$, and $70.8 \%$, respectively. It is important to note that Hengeveld et al. analyzed data from adults aged $\geq 55$ year, belonging to large cohorts ( $n=410$ to 2660 ) from different countries (U.S.A., the Netherlands, U.K., Canada, Finland, and Italy) and that they performed complex statistics to came up with the previously mentioned percentages. However, despite these differences in comparison to our study, they showed similar results when the protein intake was reported with the actual body weight for the 1.0 and $1.2 \mathrm{~g} / \mathrm{kg} / \mathrm{d}$ criteria. Nonetheless, the authors suggest using the adjusted body weight to decrease the chances of over- or underestimation $[25,51]$. 
It is important to consider this study's limitations. First, meal identification varied among studies (participant-identified [18,29]; time of the day [24]; time of the day and meal composition [14]); therefore, it impedes us to analyze the specific hour when occurred. Thus, meals could be close to one another in the time of the day but were categorized differently due to cultural traits [36]. Hence, it is difficult to fully conclude differences among meals, at least at their respective timing (i.e., breakfast, lunch, and dinner) [36]. This is one of the most important limitations to consider when translating results regarding the timing of IPI and functionality in older adults $[17,18]$. Consequently, the number of meals per day that reach adequate protein content might offer a better approach than meal timing labelling. This number has shown significant associations with higher muscle mass, strength, and lower risk of physical disability, even in samples that showed different protein eating patterns (e.g., eating more protein at dinner [15] vs. lunch [20]). Thus, it is less likely to be affected by differences in meal labelling [36].

Second, we did not analyze snacks because its categorization is more complex than with the main meals [36]. Nevertheless, further studies should include them because some protein-rich foods (e.g., dairy) might be commonly eaten at snacks [22,43]. In addition, snacks might represent as much energy as a main meal when merged [28], and possibly, the same is true with protein intake.

Third, we had no data about the foods consumed (e.g., meat, dairy, and grains). Protein sources are important because animal protein has a higher anabolic effect than vegetable proteins; this effect is mainly attributable to higher amino acid availability in animal-based foods than those coming from plant-based foods [52]. Therefore, the inclusion of data of ingested foods and food intake patterns along the determination of IPI per day and per meal might help to understand their combined role on health-related variables and which foods are associated with a lower probability of inadequacy [19,53-55].

Fourth, there were different dietary assessment methods for all studies (Table 1), and each one addresses the information from a different approach [56,57]. Moreover, the results should be interpreted cautiously because recall methods are prone to underreporting when compared to doubly labelled water, and two studies relied on one- and 2-days dietary recalls [20,29], which may poorly represent the actual nutritional intake [58,59]. Additionally, the differences in the nutritional analysis due to different food databases must be considered. It is important to highlight that data reported in this study might differ from that in the original articles due to differences in how it was analyzed. For example, Gingrich et al. [14] calculated the PDCV for each day of the 7-day diary and then averaged them. Instead, we first averaged the 7-day protein intake, and then we calculated the PDCV. As mentioned in the methods section, all databases followed the same procedure to average protein intake and made comparisons possible.

Fifth, these results came from very localized samples and must not be deemed nationally representative (Table 1). Instead, these data should be considered a glance into how the dietary protein intake patterns are in these countries. In the case of NHANES, it is a nationally representative study; however, we analyzed a sample of the available cases (200 out of 1039), and data were not weighted according to the complex sampling design; therefore, it cannot be considered as nationally representative. Comparisons of data coming from nationally representative studies deserve further research [51]. Similarly, the combined data reported here should be regarded with caution for several reasons: (1) it came from very different samples (Tables 1 and 2); (2) there are some studies reporting protein intake per meal that were not included here, and the lack of these data surely affect the reported percentages; and (3) the percentages were not weighted. A meta-analysis of the available evidence with weighted pooled prevalence would help to overcome this limitation. We hope this work stimulates the curiosity to carry out systematic reviews with meta-analysis in this area. 
The recruitment period may be another limitation. Although the recruitment years were close to one another (about 3 years), this period may yield differences in dietary patterns within countries. Similarly, the recruitment method differed among studies (Table 1). While all participants were community-dwelling, there may be differences in sociodemographic (e.g., education and income) and health-related variables (e.g., functionality and diagnosed diseases) (not included here) that may explain the differences in the outcome variables instead of the geographical localization. The addition and comparison of these variables for further studies are recommended. Additionally, mean ages ranged from 71 to 79 year; this eight-year gap might have influenced the differences observed among countries as older adults tend to eat less protein $[23,25]$. Finally, the differences in sample sizes in some comparisons were considerable ( 38 vs. 200 , min vs. max), affecting the statistical tests.

\section{Conclusions}

Inadequate protein intake at breakfast and lunch $(<30 \mathrm{~g} /$ meal $)$ was a common trait in the analyzed samples, even though most dietary protein intake patterns differed among them. Therefore, these two eating occasions might represent an opportunity for nutritional interventions in older adults in different countries. Similarly, the consumption of two or three meals per day with adequate protein content is less frequent. Further research is recommended to analyze if better dietary protein intake patterns match with better functionality or other health-related variables.

Supplementary Materials: The following are available online at http://www.mdpi.com/2072-6643/12/10/3156/s1, Table S1: Women's main characteristics and protein intake variables by country. Table S2: Men's main characteristics and protein intake variables by country. Table S3: Detailed inadequate protein intake per day and meal in older adults from four countries. Figure S1: Comparison of inadequate protein intake per day with different cut points among four countries in women and men. Figure S2: Inadequate protein intake per meal (breakfast, lunch, and dinner) compared among four countries depending on the protein content for each meal as $<30 \mathrm{~g} / \mathrm{meal}$ or $<0.4 \mathrm{~g} / \mathrm{kg}$ body mass $/$ meal in women and men. Figure S3: The number of meals per day containing $\geq 30 \mathrm{~g}$ protein or $\geq 0.4 \mathrm{~g}$ protein $/ \mathrm{kg}$ body mass each, in women and men and compared among countries.

Author Contributions: Conceptualization, A.G.-G., M.d.J.O.-A., F.T.-N., and J.R.L.-T.; methodology, A.G.-G., M.d.J.O.-A., F.T.-N., M.A.-R., and M.G.-B.; formal analysis, A.G.-G. and R.G.G.-M.; investigation, A.G.-G.; resources, M.d.J.O.-A. and J.R.L.-T.; data curation, A.G.-G. and R.G.G.-M.; writing-original draft preparation, A.G.-G.; writing-review and editing, M.d.J.O.-A., F.T.-N., M.A.-R., R.G.G.-M., M.G.-B., and J.R.L.-T.; visualization, A.G.-G.; project administration, A.G.-G. and J.R.L.-T. All authors have read and agreed to the published version of the manuscript.

Funding: This research received no external funding.

Acknowledgments: The authors would like to thank to Danielle Cardon-Thomas and Carolyn Greig, from the School of Sport, Exercise and Rehabilitation Sciences and the MRC-Versus Arthritis Centre for Musculoskeletal Ageing Research, the University of Birmingham, UK and to Anne Gingrich and Eva Kiesswetter from the Friedrich-Alexander-Universität Erlangen-Nürnberg, Germany, for their kindly disposition to provide their data to carry out this study.

Conflicts of Interest: The authors declare no conflict of interest.

\section{References}

1. Jafarinasabian, P.; Inglis, J.E.; Reilly, W.; Kelly, O.J.; Ilich, J.Z. Aging Human Body: Changes in Bone, Muscle and Body Fat with Consequent Changes in Nutrient Intake. J. Endocrinol. 2017, 234, R37-R51. [CrossRef] [PubMed]

2. Fulop, T.; Larbi, A.; Khalil, A.; Cohen, A.A.; Witkowski, J.M. Are We Ill Because We Age? Front. Physiol. 2019, 10, 1508. [CrossRef] [PubMed]

3. Seals, D.R.; Justice, J.N.; Larocca, T.J. Physiological Geroscience: Targeting Function to Increase Healthspan and Achieve Optimal Longevity. J. Physiol. 2016, 594, 2001-2024. [CrossRef]

4. Martone, A.M.; Marzetti, E.; Calvani, R.; Picca, A.; Tosato, M.; Santoro, L.; Di Giorgio, A.; Nesci, A.; Sisto, A.; Santoliquido, A.; et al. Exercise and Protein Intake: A Synergistic Approach against Sarcopenia. BioMed Res. Int. 2017, 2017, 2672435. [CrossRef] 
5. Robinson, S.M.; Reginster, J.Y.; Rizzoli, R.; Shaw, S.C.; Kanis, J.A.; Bautmans, I.; Bischoff-Ferrari, H.; Bruyère, O.; Cesari, M.; Dawson-Hughes, B.; et al. Does Nutrition Play a Role in the Prevention and Management of Sarcopenia? Clin. Nutr. 2018, 37, 1121-1132. [CrossRef] [PubMed]

6. Tieland, M.; Trouwborst, I.; Clark, B.C. Skeletal Muscle Performance and Ageing. J. Cachexia. Sarcopenia Muscle 2018, 9, 3-19. [CrossRef]

7. Landi, F.; Calvani, R.; Tosato, M.; Martone, A.M.; Ortolani, E.; Savera, G.; D’Angelo, E.; Sisto, A.; Marzetti, E. Protein Intake and Muscle Health in Old Age: From Biological Plausibility to Clinical Evidence. Nutrients 2016, 8, 295. [CrossRef]

8. Bauer, J.; Biolo, G.; Cederholm, T.; Cesari, M.; Cruz-Jentoft, A.J.; Morley, J.E.; Phillips, S.; Sieber, C.; Stehle, P.; Teta, D.; et al. Evidence-Based Recommendations for Optimal Dietary Protein Intake in Older People: A Position Paper from the PROT-AGE Study Group. J. Am. Med. Dir. Assoc. 2013, 14, 542-559. [CrossRef]

9. Coelho-Júnior, H.; Milano-Teixeira, L.; Rodrigues, B.; Bacurau, R.; Marzetti, E.; Uchida, M. Relative Protein Intake and Physical Function in Older Adults: A Systematic Review and Meta-Analysis of Observational Studies. Nutrients 2018, 10, 1330. [CrossRef]

10. Mendonça, N.; Granic, A.; Hill, T.R.; Siervo, M.; Mathers, J.C.; Kingston, A.; Jagger, C. Protein Intake and Disability Trajectories in Very Old Adults: The Newcastle 85+ Study. J. Am. Geriatr. Soc. 2019, 67, 50-56. [CrossRef]

11. Murphy, C.H.; Oikawa, S.Y.; Phillips, S.M. Dietary Protein to Maintain Muscle Mass in Aging: A Case for per-Meal Protein Recommendations. J. Frailty Aging 2016, 5, 49-58. [CrossRef] [PubMed]

12. Hudson, J.L.; Bergia, R.E.I.; Campbell, W.W. Protein Distribution and Muscle-Related Outcomes: Does the Evidence Support the Concept? Nutrients 2020, 12, 1441. [CrossRef] [PubMed]

13. Kim, I.Y.; Schutzler, S.; Schrader, A.M.; Spencer, H.J.; Azhar, G.; Wolfe, R.R.; Ferrando, A.A. Protein Intake Distribution Pattern Does Not Affect Anabolic Response, Lean Body Mass, Muscle Strength or Function over 8 Weeks in Older Adults: A Randomized-Controlled Trial. Clin. Nutr. 2018, 37, 488-493. [CrossRef] [PubMed]

14. Gingrich, A.; Spiegel, A.; Kob, R.; Schoene, D.; Skurk, T.; Hauner, H.; Siebe, C.C.; Volkert, D.; Kiesswetter, E. Amount, Distribution, and Quality of Protein Intake Are Not Associated with Muscle Mass, Strength, and Power in Healthy Older Adults without Functional Limitations-An Enable Study. Nutrients 2017, 9, 1358. [CrossRef] [PubMed]

15. Loenneke, J.P.; Loprinzi, P.D.; Murphy, C.H.; Phillips, S.M. Per Meal Dose and Frequency of Protein Consumption Is Associated with Lean Mass and Muscle Performance. Clin. Nutr. 2016, 35, 1506-1511. [CrossRef] [PubMed]

16. Moore, D.R.; Churchward-Venne, T.A.; Witard, O.; Breen, L.; Burd, N.A.; Tipton, K.D.; Phillips, S.M. Protein Ingestion to Stimulate Myofibrillar Protein Synthesis Requires Greater Relative Protein Intakes in Healthy Older versus Younger Men. J. Gerontol. A Biol. Sci. Med. Sci. 2015, 70, 57-62. [CrossRef]

17. Buckner, S.L.; Loenneke, J.P.; Loprinzi, P.D. Protein Timing during the Day and Its Relevance for Muscle Strength and Lean Mass. Clin. Physiol. Funct. Imaging 2017, 38, 332-337. [CrossRef]

18. Gaytán-González, A.; Ocampo-Alfaro, M.D.J.; Arroniz-Rivera, M.; Torres-Naranjo, F.; González-Mendoza, R.G.; Gil-Barreiro, M.; López-Taylor, J.R. Inadequate Protein Intake at Specific Meals Is Associated with Higher Risk of Impaired Functionality in Middle to Older Aged Mexican Adults. J. Aging Res. 2019, 2019, 6597617. [CrossRef]

19. Otsuka, R.; Kato, Y.; Tange, C.; Nishita, Y.; Tomida, M.; Imai, T.; Ando, F.; Shimokata, H.; Arai, H. Protein Intake per Day and at Each Daily Meal and Skeletal Muscle Mass Declines among Older Community Dwellers in Japan. Public Health Nutr. 2019, 23, 1090-1097. [CrossRef]

20. Gaytán-González, A.; Ocampo-Alfaro, M.D.J.; Torres-Naranjo, F.; Arroniz-Rivera, M.; González-Mendoza, R.G.; Gil-Barreiro, M.; López-Taylor, J.R. The Consumption of Two or Three Meals per Day with Adequate Protein Content Is Associated with Lower Risk of Physical Disability in Mexican Adults Aged 60 Years and Older. Geriatrics 2020, 5, 1. [CrossRef]

21. Hayashi, A.P.; de Capitani, M.D.; Dias, S.F.; de Souza Gonçalves, L.; Fernandes, A.L.; Jambassi-Filho, J.C.; de Santana, D.A.; Lixandrão, M.; dos Santos Pereira, R.T.; Riani, L.; et al. Number of High-Protein Containing Meals Correlates with Muscle Mass in Pre-Frail and Frail Elderly. Eur. J. Clin. Nutr. 2020, 74, 1047-1053. [CrossRef] [PubMed] 
22. Tieland, M.; den Berg, K.J.B.-V.; van Loon, L.J.C.; de Groot, L.C.P.G.M. Dietary Protein Intake in Dutch Elderly People: A Focus on Protein Sources. Nutrients 2015, 7, 9697-9706. [CrossRef]

23. Rousset, S.; Mirand, P.P.; Brandolini, M.; Martin, J.-F.; Boirie, Y. Daily Protein Intakes and Eating Patterns in Young and Elderly French. Br. J. Nutr. 2003, 90, 1107-1115. [CrossRef]

24. Cardon-Thomas, D.K.; Riviere, T.; Tieges, Z.; Greig, C.A. Dietary Protein in Older Adults: Adequate Daily Intake but Potential for Improved Distribution. Nutrients 2017, 9, 184. [CrossRef] [PubMed]

25. Berner, L.A.; Becker, G.; Wise, M.; Doi, J. Characterization of Dietary Protein among Older Adults in the United States: Amount, Animal Sources, and Meal Patterns. J. Acad. Nutr. Diet. 2013, 113, 809-815. [CrossRef] [PubMed]

26. Bollwein, J.; Diekmann, R.; Kaiser, M.J.; Bauer, J.M.; Uter, W.; Sieber, C.C.; Volkert, D. Distribution but Not Amount of Protein Intake Is Associated with Frailty: A Cross-Sectional Investigation in the Region of Nürnberg. Nutr. J. 2013, 12, 109. [CrossRef] [PubMed]

27. Ten Haaf, D.S.M.; Van Dongen, E.J.I.; Nuijten, M.A.H.; Eijsvogels, T.M.H.; De Groot, L.C.P.G.M.; Hopman, M.T.E. Protein Intake and Distribution in Relation to Physical Functioning and Quality of Life in Community-Dwelling Elderly People: Acknowledging the Role of Physical Activity. Nutrients 2018, 10, 506. [CrossRef]

28. Huseinovic, E.; Winkvist, A.; Slimani, N.; Park, M.K.; Freisling, H.; Boeing, H.; Buckland, G.; Schwingshackl, L.; Weiderpass, E.; Rostgaard-Hansen, A.L.; et al. Meal Patterns across Ten European Countries-Results from the European Prospective Investigation into Cancer and Nutrition (EPIC) Calibration Study. Public Health Nutr. 2016, 19, 2769-2780. [CrossRef]

29. Centers for Disease Control and Prevention. National Health and Nutrition Examination Survey (NHANES) 2015-2016. Available online: https://wwwn.cdc.gov/nchs/nhanes/ContinuousNhanes/Default. aspx?Begin Year=2015 (accessed on 2 April 2019).

30. Volker, M.A. Reporting Effect Size Estimates in School Psychology Research. Psychol. Sch. 2006, 43, 653-672. [CrossRef]

31. Cohen, J. Statistical Power Analysis for the Behavioral Sciences, 2nd ed.; Lawerence Erlbaum Associates: New York, NY, USA, 1988.

32. Sullivan, G.M.; Feinn, R. Using Effect Size-or Why the p Value Is Not Enough. J. Grad. Med. Educ. 2012, 4, 279-282. [CrossRef]

33. Isanejad, M.; Mursu, J.; Sirola, J.; Kröger, H.; Rikkonen, T.; Tuppurainen, M.; Erkkilä, A.T. Dietary Protein Intake Is Associated with Better Physical Function and Muscle Strength among Elderly Women. Br. J. Nutr. 2016, 115, 1281-1291. [CrossRef] [PubMed]

34. Rahi, B.; Colombet, Z.; Gonzalez-Colaço, H.M.; Dartigues, J.F.; Boirie, Y.; Letenneur, L.; Feart, C. Higher Protein but Not Energy Intake Is Associated with a Lower Prevalence of Frailty among Community-Dwelling Older Adults in the French Three-City Cohort. J. Am. Med. Dir. Assoc. 2016, 17, 672.e7-672.e11. [CrossRef] [PubMed]

35. Coelho-Júnior, H.J.; Rodrigues, B.; Uchida, M.; Marzetti, E. Low Protein Intake Is Associated with Frailty in Older Adults: A Systematic Review and Meta-Analysis of Observational Studies. Nutrients 2018, 10, 1334. [CrossRef] [PubMed]

36. Leech, R.M.; Worsley, A.; Timperio, A.; McNaughton, S.A. Understanding Meal Patterns: Definitions, Methodology and Impact on Nutrient Intake and Diet Quality. Nutr. Res. Rev. 2015, 28, 1-21. [CrossRef]

37. Yasuda, J.; Asako, M.; Arimitsu, T.; Fujita, S. Skipping Breakfast Is Associated with Lower Fat-Free Mass in Healthy Young Subjects: A Cross-Sectional Study. Nutr. Res. 2018, 60, 26-32. [CrossRef] [PubMed]

38. Wong, M.M.H.; So, W.K.W.; Choi, K.C.; Cheung, R.; Chan, H.Y.L.; Sit, J.W.H.; Ho, B.; Li, F.; Lee, T.Y.; Chair, S.Y. Malnutrition Risks and Their Associated Factors among Home-Living Older Chinese Adults in Hong Kong: Hidden Problems in an Affluent Chinese Community. BMC Geriatr. 2019, 19, 138. [CrossRef] [PubMed]

39. Deutz, N.E.P.; Ashurst, I.; Ballesteros, M.D.; Bear, D.E.; Cruz-Jentoft, A.J.; Genton, L.; Landi, F.; Laviano, A.; Norman, K.; Prado, C.M. The Underappreciated Role of Low Muscle Mass in the Management of Malnutrition. J. Am. Med. Dir. Assoc. 2019, 20, 22-27. [CrossRef]

40. Ballon, A.; Neuenschwander, M.; Schlesinger, S. Breakfast Skipping Is Associated with Increased Risk of Type 2 Diabetes among Adults: A Systematic Review and Meta-Analysis of Prospective Cohort Studies. J. Nutr. 2019, 149, 106-113. [CrossRef] 
41. Hutchison, A.T.; Heilbronn, L.K. Metabolic Impacts of Altering Meal Frequency and Timing-Does When We Eat Matter? Biochimie 2016, 124, 187-197. [CrossRef]

42. Ten Haaf, D.S.M.; de Regt, M.F.; Visser, M.; Witteman, B.J.M.; de Vries, J.H.M.; Eijsvogels, T.M.H.; Hopman, M.T.E. Insufficient Protein Intake Is Highly Prevalent among Physically Active Elderly. J. Nutr. Health Aging 2018, 22, 1112-1114. [CrossRef]

43. Smeuninx, B.; Greig, C.A.; Breen, L. Amount, Source and Pattern of Dietary Protein Intake across the Adult Lifespan: A Cross-Sectional Study. Front. Nutr. 2020, 7, 25. [CrossRef]

44. Ruiz Valenzuela, R.E.; Ponce, J.A.; Morales-Figueroa, G.G.; Muro, K.A.; Carreón, V.R.; Alemán-Mateo, H. Insufficient Amounts and Inadequate Distribution of Dietary Protein Intake in Apparently Healthy Older Adults in a Developing Country: Implications for Dietary Strategies to Prevent Sarcopenia. Clin. Interv. Aging 2013, 8, 1143-1148. [CrossRef]

45. Tessier, A.J.; Chevalier, S. An Update on Protein, Leucine, Omega-3 Fatty Acids, and Vitamin D in the Prevention and Treatment of Sarcopenia and Functional Decline. Nutrients 2018, 10, 1099. [CrossRef]

46. Van Til, A.J.; Naumann, E.; Cox-Claessens, I.J.H.M.; Kremer, S.; Boelsma, E.; van der Schueren, M.A.E. Effects of the Daily Consumption of Protein Enriched Bread and Protein Enriched Drinking Yoghurt on the Total Protein Intake in Elderly in a Rehabilitation Centre: A Single Blind Randomised Controlled Trial. J. Nutr. Health Aging 2015, 19, 525-530. [CrossRef]

47. Host, A.; McMahon, A.T.; Walton, K.; Charlton, K. Factors Influencing Food Choice for Independently Living Older People-A Systematic Literature Review. J. Nutr. Gerontol. Geriatr. 2016, 35, 67-94. [CrossRef]

48. Pennings, B.; Groen, B.B.L.; van Dijk, J.-W.; de Lange, A.; Kiskini, A.; Kuklinski, M.; Senden, J.M.G.; van Loon, L.J.C. Minced Beef Is More Rapidly Digested and Absorbed than Beef Steak, Resulting in Greater Postprandial Protein Retention in Older Men. Am. J. Clin. Nutr. 2013, 98, 121-128. [CrossRef]

49. Beasley, J.M.; Wertheim, B.C.; LaCroix, A.Z.; Prentice, R.L.; Neuhouser, M.L.; Tinker, L.F.; Kritchevsky, S.; Shikany, J.M.; Eaton, C.; Chen, Z.; et al. Biomarker-Calibrated Protein Intake and Physical Function in the Women's Health Initiative. J. Am. Geriatr. Soc. 2013, 61, 1863-1871. [CrossRef]

50. Houston, D.K.; Tooze, J.A.; Garcia, K.; Visser, M.; Rubin, S.; Harris, T.B.; Newman, A.B.; Kritchevsky, S.B. Protein Intake and Mobility Limitation in Community-Dwelling Older Adults: The Health ABC Study. J. Am. Geriatr. Soc. 2017, 65, 1705-1711. [CrossRef]

51. Hengeveld, L.M.; Boer, J.M.A.; Gaudreau, P.; Heymans, M.W.; Jagger, C.; Mendonça, N.; Ocké, M.C.; Presse, N.; Sette, S.; Simonsick, E.M.; et al. Prevalence of Protein Intake below Recommended in Community-dwelling Older Adults: A Meta-analysis across Cohorts from the PROMISS Consortium. J. Cachexia. Sarcopenia Muscle 2020. [CrossRef]

52. Berrazaga, I.; Micard, V.; Gueugneau, M.; Walrand, S. The Role of the Anabolic Properties of Plant-versus Animal-Based Protein Sources in Supporting Muscle Mass Maintenance: A Critical Review. Nutrients 2019, 11, 1825. [CrossRef]

53. Hengeveld, L.M.; Pelgröm, A.D.A.; Visser, M.; Boer, J.M.A.; Haveman-Nies, A.; Wijnhoven, H.A.H. Comparison of Protein Intake per Eating Occasion, Food Sources of Protein and General Characteristics between Community-Dwelling Older Adults with a Low and High Protein Intake. Clin. Nutr. ESPEN 2019, 29, 165-174. [CrossRef]

54. Gingrich, A.; Spiegel, A.; Gradl, J.E.; Skurk, T.; Hauner, H.; Sieber, C.C.; Volkert, D.; Kiesswetter, E. Daily and Per-Meal Animal and Plant Protein Intake in Relation to Muscle Mass in Healthy Older Adults without Functional Limitations: An Enable Study. Aging Clin. Exp. Res. 2019, 31, 1271-1281. [CrossRef] [PubMed]

55. Murakami, K.; Livingstone, M.B.E.; Sasaki, S. Meal-Specific Dietary Patterns and Their Contribution to Overall Dietary Patterns in the Japanese Context: Findings from the 2012 National Health and Nutrition Survey, Japan. Nutrition 2019, 59, 108-115. [CrossRef]

56. Biró, G.; Hulshof, K.F.A.M.; Ovesen, L.; Amorim Cruz, J.A. Selection of Methodology to Assess Food Intake. Eur. J. Clin. Nutr. 2002, 56 (Suppl. 2), S25-S32. [CrossRef]

57. Burrows, T.L.; Ho, Y.Y.; Rollo, M.E.; Collins, C.E. Validity of Dietary Assessment Methods When Compared to the Method of Doubly Labeled Water: A Systematic Review in Adults. Front. Endocrinol. 2019, 10, 850. [CrossRef]

58. Ma, Y.; Olendzki, B.C.; Pagoto, S.L.; Hurley, T.G.; Magner, R.P.; Ockene, I.S.; Schneider, K.L.; Merriam, P.A.; Hébert, J.R. Number of 24-Hour Diet Recalls Needed to Estimate Energy Intake. Ann. Epidemiol. 2009, 19,553-559. [CrossRef] [PubMed] 
59. Basiotis, P.P.; Welsh, S.O.; Cronin, F.J.; Kelsay, J.L.; Mertz, W. Number of Days of Food Intake Records Required to Estimate Individual and Group Nutrient Intakes with Defined Confidence. J. Nutr. 1987, 117, 1638-1641. [CrossRef] [PubMed]

Publisher's Note: MDPI stays neutral with regard to jurisdictional claims in published maps and institutional affiliations.

(C) 2020 by the authors. Licensee MDPI, Basel, Switzerland. This article is an open access article distributed under the terms and conditions of the Creative Commons Attribution (CC BY) license (http://creativecommons.org/licenses/by/4.0/). 